\title{
TINGKAT PENERIMAAN DAN HARGA POKOK MIE TELUR KERING YANG DIFORTIFIKASI SURIMI IKAN LAYANG
}

\author{
Mohammad Noor ${ }^{\star}$, Sugiyono*) dan Ijah Muljanah*)
}

\begin{abstract}
ABSTRAK
Telah dilakukan penelitian pengolahan mie telur kering dengan penambahan surimi ikan layang sebesar 10\%, 20\%, 30\%. Penelitian ini bertujuan untuk mengetahui pengaruh penambahan daging ikan terhadap tingkat penerimaan produk.

Hasil penelitian menunjukkan bahwa mie yang paling disukai adalah mie dengan penambahan surimi sebesar $10 \%$ yang meningkatkan kadar protein mie dari $12,9 \%$ menjadi $13,53 \%$ dan meningkatkan harga dari Rp3.139,61 menjadi Rp 3.645,75/kg. Sedangkan penambahan surimi sebesar $20 \%$ meningkatkan kadar protein mie dari $12,90 \%$ menjadi $17,29 \%$ dan meningkatkan harga dari Rp 3.139,61 menjadi Rp 4.846,34/kg. Mie yang ditambah surimi lebih dari $20 \%$ kurang disenangi para panelis. Harga mie yang difortifikasi surimi ikan juga tergantung harga ikan itu sendiri.
\end{abstract}

\section{ABSTRACT: Acceptability and price of dried egg noodle fortified by scad surimi. By: Mohammad Noor, Sugiyono and Ijah Muljanah.}

An experiment on dried egg noodle processing fortified by scad surimi at 10\%, 20\%, 30\% has been carried out. The experiment aimed to find the acceptable level of fortification.

The result showed that the most acceptable level was the addition of $10 \%$ surimi resulting in an increase of protein content from $12,90 \%$ to $13.53 \%$, and the price from $R p 3,139.61$ to $R p$ $3,645.75 / \mathrm{kg}$. Dried egg noodle fortified with more than $20 \%$ surimi was less acceptable. The price of the product also depended on the price of scad as a raw material for surimi.

KEYWORDS: Egg noodle; surimi; protein content; price.

\section{PENDAHULUAN}

Usaha perikanan pada dasarnya merupakan kegiatan pemanfaatan sumber daya hayati perairan, untuk tujuan memenuhi berbagai kebutuhan manusia. Bagi negara berkembang usaha pembangunan perikanan memungkinkan terbukanya kesempatan kerja untuk mengelola sumber daya perikanan dengan lebih baik, meningkatkan kemampuan ekonomi, dan memperbaiki mutu gizi penduduk.

Dalam kerangka Pembangunan Ekonomi Nasional, peran perikanan antara lain berupa sumbangannya terhadap konsumsi protein domestik dan peningkatan ekspor bagi perolehan devisa (Anonim., 1984).

Sumber protein di Indonesia hampir $89 \%$ terdiri atas protein nabati, $67 \%$ di antaranya berasal dari serealia. Rendahnya jumlah protein yang berasal dari ikan karena belum banyak hasil produk olahan dari ikan seperti halnya produk olahan nabati.

Mie tergolong makanan dengan bahan dasar tepung dan bahan tambahan lain, membentuk suatu formula yang menghasilkan suatu produk dengan sifat struktur tertentu (Maltz, 1981). Mie ikan merupakan salah satu alternatif upaya diversifikasi produk makanan olahan berprotein ikani yang potensial untuk dikembangkan.

Untuk menambah protein ikan dalam produk mie, dilakukan percobaan fortifikasi dengan pemanfaatan daging ikan layang (Depcapterus sp.) sebagai bahan pengkaya. Dengan penelitian ini ingin diketahui berapa persen penambahan surimi ikan layang dalam produk mie yang dapat diterima panelis serta apakah secara ekonomis dan komersial produk ini layak diusahakan. Apabila produk ini dapat dikembangkan, maka

Peneliti pada Balai Penelitian Perikanan Laut 
akan membuka lapangan usaha/kesempatan kerja dan menaikkan nilai tambah ikan layang.

\section{BAHAN DAN METODE}

\section{Bahan}

Bahan yang digunakan dalam penelitian ini adalah surimi ikan layang yang ditambahkan ke dalam adonan dengan konsentrasi $10 \%, 20 \%$, $30 \%$. Jenis ikan yang digunakan adalah surimi ikan layang (Depcapterus sp). Ikan layang dibeli dari Juwana (Jawa Tengah). Ikan dikemas dalam kotak berinsulasi, diberi es dan dibawa ke laboratorium Instalasi Penelitian Perikanan Laut (Inlitkanlut) Slipi, Jakarta. Ikan di fillet dan dagingnya dipisahkan dari kulit dan tulang, kemudian dilumatkan. Daging lumat yang dihasilkan dicuci dengan air es sampai air cucian bebas lemak dan bebas bau amis serta berwarna jernih. Daging yang diperoleh disentrifus sehingga kadar airnya sekitar $70 \%$.

\section{Peralatan}

Peralatan yang digunakan dalam penelitian terdiri atas baskom, talenan, ember, pengocok, gilingan ikan, alat pencetak, loyang, oven, panci, dan kompor. Nilai peralatan ini akan dihitung biaya penyusutannya dalam analisis ekonomi sebagai biaya tetap.

\section{Metode}

Dalam penelitian ini dibuat produk mie telur kering yang difortifikasi surimi ikan layang dengan berbagai komposisi perlakuan. Biayabiaya yang menyangkut pengeluaranpengeluaran diteliti, bertolak dari perhitungan biaya impas (harga pokok). Perbandingan antara masukan dan keluaran akan dianalisis.

Sebagai perbandingan, juga dilakukan analisis dan pengamatan terhadap empat produk mie kering yang ada di pasaran.

\section{Analisis Biaya}

Untuk mengetahui sampai sejauh mana usaha pembuatan mie itu menguntungkan atau tidak, dilakukan perhitungan titik impas (Reksoprayitno, 1981) dengan rumus sebagai berikut:
Biaya pulang pokok/Titik Impas:

$$
\begin{array}{cl} 
& \mathrm{PT}=\mathrm{BT}+\mathrm{BTT} \\
\text { Keuntungan } & =\mathrm{PT}>\mathrm{BT}+\mathrm{BTT} \\
\text { Rugi } & =\mathrm{PT}<\mathrm{BT}+\mathrm{BTT} \\
\multicolumn{1}{c}{\text { di mana: }} & \mathrm{PT} \quad=\text { Pendapatan Total } \\
& \mathrm{BT} \quad=\text { Biaya Tetap } \\
& \mathrm{BTT}=\text { Biaya Tidak Tetap }
\end{array}
$$

Kegiatan ekonomi dilakukan untuk mencapai keuntungan optimal. Keuntungan adalah perbedaan antara total pendapatan dan total biaya, karena pendapatan dan keuntungan juga akan tergantung pada pengeluaran (Riyanto, 1980; Ariyoto dan Kresnohadi, 1978; Nicholson, 1978; Henderson and Quant, 1980; Peter, 1982).

\section{HASIL DAN PEMBAHASAN}

\section{Komposisi Kimiawi Mie Kering}

Hasil analisis proksimat terhadap produk mie kering dari pasar umum dan mie telur berbagai komposisi perlakuan penambahan surimi ikan disajikan dalam Tabel 1. Dari Tabel 1 tampak bahwa kadar air mie ikan layang cenderung meningkat dengan makin meningkatnya persentase ikan yang digunakan. Peningkatan kadar air ini disebabkan terjadinya peningkatan protein yang memiliki kemampuan meningkatkan air lebih besar. Protein pada dasarnya bersifat hidrofilik. Hal ini ditunjukkan dengan makin tingginya protein pada mie, makin tinggi pula kadar air (Basmal et al., 1995).

Penambahan daging surimi ikan layang ke dalam mie sebesar $10 \%$ meningkatkan kadar protein mie dari $12,9 \%$ menjadi $13,53 \%$, dengan penambahan biaya daging surimi ikan sebesar Rp 625,- (per resep) atau Rp 1.177,56/kg. Penambahan daging sebanyak $20 \%$ meningkatkan kadar protein dari $12,9 \%$ menjadi $17,29 \%$, dengan penambahan biaya daging surimi ikan Rp 1.250 (per resep) atau $\mathrm{Rp} 2.377,74 / \mathrm{kg}$. Sedang penambahan $30 \%$ meningkatkan kadar protein dari $12,9 \%$ menjadi $17,35 \%$ dengan penambahan biaya daging surimi ikan Rp 1.875,- (per resep) atau Rp 3.507,16/kg.

Fortifikasi dengan ikan juga berpengaruh terhadap kandungan lemak mie. Makin tinggi persentase daging surimi ikan yang digunakan, 
Tabel 1. Komposisi kimia mie kering yang dijual di pasaran dan mie rebus yang difortifikasi dengan surimi.

Table 1. Chemical composition of dry noodles at commercial market and boiled noodles fortified by scad surimi.

\begin{tabular}{lcrrrr}
\hline \multirow{2}{*}{$\begin{array}{c}\text { Parameter } \\
\text { Mie kering di pasar } \\
\text { Dry noodles at market } \\
\text { (\%) }\end{array}$} & \multicolumn{3}{c}{$\begin{array}{c}\text { Persentase campuran ikan } \\
\text { (Percentage of minced fish) } \\
\text { (\%) }\end{array}$} \\
\cline { 3 - 6 } & 10.88 & $\mathbf{0}$ & $\mathbf{1 0}$ & $\mathbf{2 0}$ & $\mathbf{3 0}$ \\
\hline Kelembaban (Moisture) & 12.33 & 12.90 & 13.53 & 17.29 & 17.35 \\
Protein & 1.18 & 1.57 & 1.87 & 2.28 & 2.31 \\
Abu (Ash) & 1.78 & 2.37 & 2.56 & 2.39 & 2.58 \\
Lemak (Fat) & & & & 11.29 & 10.99 \\
\hline
\end{tabular}

cenderung makin tinggi pula kandungan lemak pada mie. Sebagai pembanding, dilakukan pula analisis terhadap sejumlah produk mie yang ada di pasaran.

Pada Tabel 1 tampak bahwa kadar air ratarata mie di pasaran umum $10,88 \%$, sedangkan mie dengan kadar ikan layang (10\%) kadar airnya $10,18 \%$. Hasil ini memperlihatkan perbedaan kadar air mie ikan lebih rendah sebesar $0,70 \%$ dari mie yang ada di pasaran.
Kadar protein rata-rata mie di pasaran umum sekitar $12,33 \%$. Sementara kadar protein mie kering yang difortifikasi surimi ikan layang $(10 \%)$ lebih tinggi, yaitu $13,53 \%$. Berdasarkan data ini, penambahan daging ikan ke dalam mie mampu menaikkan kadar protein mie sampai 1,20\% lebih besar dibanding mie pasaran.

Hasil pengujian organoleptik mie telur kering yang difortifikasi surimi ikan layang pada penelitian ini disajikan dalam Tabel 2.

Tabel 2. Nilai organoleptik mie telur kering yang difortifikasi dengan surimi ikan layang.

Table 2. Organoleptic score of dry egg noodles fortified by scad surimi.

\begin{tabular}{|c|c|c|c|c|c|}
\hline $\begin{array}{c}\text { Persentase campuran ikan } \\
\text { Percentage of minced fish }\end{array}$ & $\begin{array}{l}\text { Tampilan } \\
\text { Appearance }\end{array}$ & $\begin{array}{l}\text { Warna } \\
\text { Color }\end{array}$ & $\begin{array}{l}\text { Bau } \\
\text { Smell }\end{array}$ & $\begin{array}{l}\text { Rasa } \\
\text { Taste }\end{array}$ & $\begin{array}{l}\text { Tekstur } \\
\text { Texture }\end{array}$ \\
\hline \multicolumn{6}{|l|}{ Kontrol (Control): } \\
\hline - awal (initial) & 6.7 & 6.9 & 6.0 & 5.8 & 7.4 \\
\hline - akhir (end) & 6.6 & 6.8 & 5.8 & 5.6 & 7.4 \\
\hline \multicolumn{6}{|l|}{$10 \%$} \\
\hline - awal (initial) & 6.2 & 6.0 & 6.7 & 6.3 & 7.1 \\
\hline - akhir (end) & 6.0 & 6.0 & 5.8 & 6.0 & 7.0 \\
\hline \multicolumn{6}{|l|}{$20 \%$} \\
\hline - awal (initial) & 6.0 & 5.8 & 6.8 & 6.5 & 6.9 \\
\hline - akhir (end) & 6.0 & 5.5 & 5.6 & 6.1 & 6.5 \\
\hline \multicolumn{6}{|l|}{$30 \%$} \\
\hline - awal (initial) & 5.2 & 5.6 & 6.0 & 5.4 & 5.5 \\
\hline - akhir (end) & 5.0 & 4.5 & 5.0 & 5.0 & 5.2 \\
\hline
\end{tabular}

Surnber (Source): Basmal et al., 1995. 

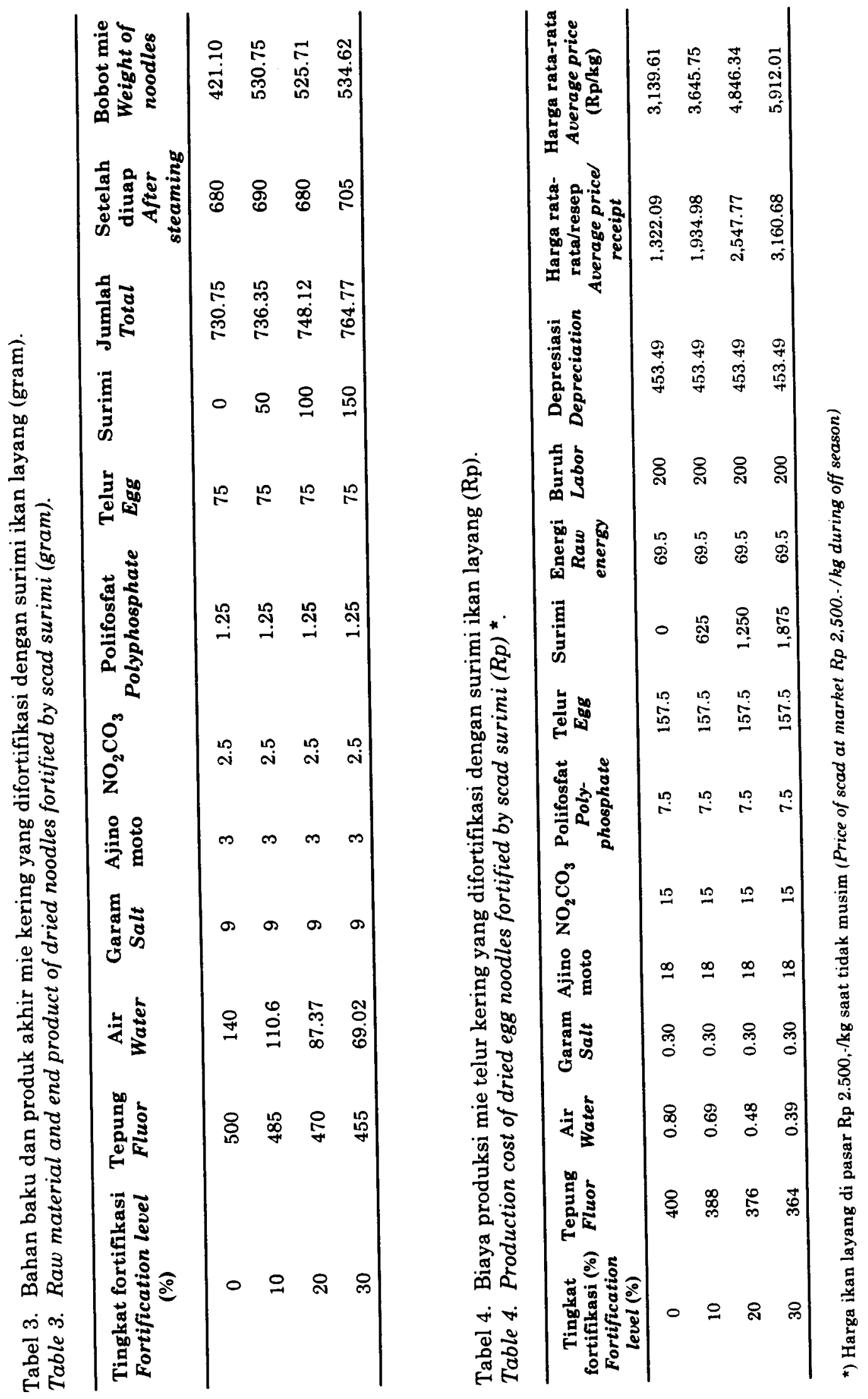


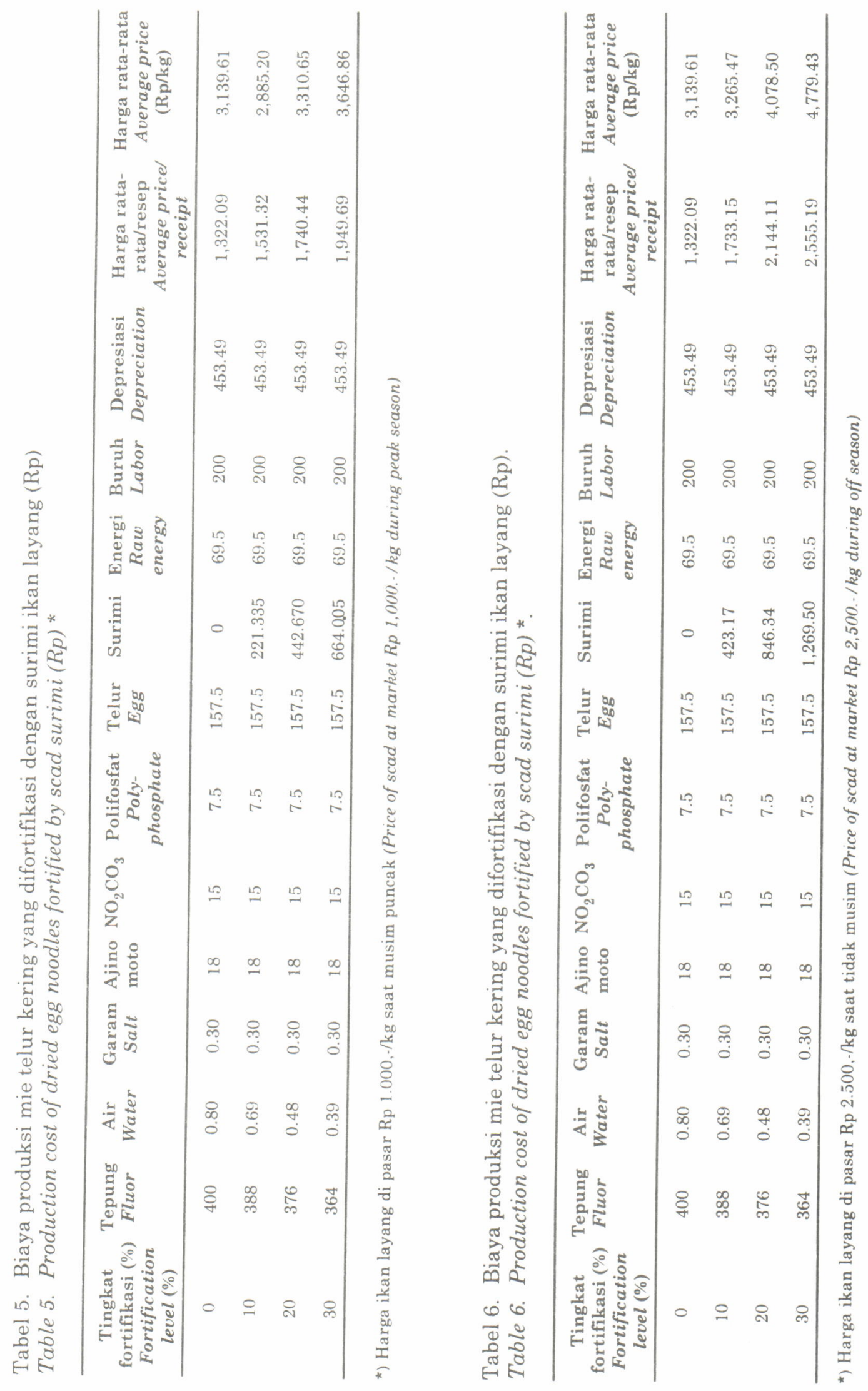


Tabel 7. Biaya produksi mie telur kering yang difortifikasi dengan surimi ikan layang.

Table 7. Production cost of dried egg noodles fortified by scad surimi.

\begin{tabular}{|c|c|c|c|c|c|c|}
\hline \multirow[t]{2}{*}{$\begin{array}{c}\text { Tingkat } \\
\text { fortifikasi } \\
\text { Fortification } \\
\text { level }\end{array}$} & \multicolumn{2}{|c|}{$\begin{array}{c}\text { Ikan layang (Scad) } \\
(\mathrm{Rp} 2,500 / \mathrm{kg})\end{array}$} & \multicolumn{2}{|c|}{$\begin{array}{c}\text { Ikan layang (Scad) } \\
(\operatorname{Rp~} 1,000 / \mathrm{kg})\end{array}$} & \multicolumn{2}{|c|}{$\begin{array}{l}\text { Rata-rata harga ikan layang } \\
\text { Average price of scad } \\
\text { (Rp } 1,750 / \mathrm{kg})\end{array}$} \\
\hline & $\begin{array}{l}\text { Mie kering } \\
\text { Dry noodles }\end{array}$ & $\begin{array}{l}\text { Biaya } \\
\text { Cost } \\
(\%)\end{array}$ & $\begin{array}{l}\text { Mie kering } \\
\text { Dry noodles }\end{array}$ & $\begin{array}{l}\text { Biaya } \\
\text { Cost } \\
(\%)\end{array}$ & $\begin{array}{l}\text { Mie kering } \\
\text { Dry noodles } \\
(\mathrm{Rp} / \mathrm{kg})\end{array}$ & $\begin{array}{l}\text { Biaya } \\
\text { Cost } \\
(\%)\end{array}$ \\
\hline 0 & $3,139.61$ & 0 & $3,139.61$ & 0 & $3,139.61$ & 0 \\
\hline 10 & $3,645.75$ & 16.12 & $2,885.20$ & -8.10 & $3,265.47$ & 4.01 \\
\hline 20 & $4,846.34$ & 54.36 & $3,310.65$ & 5.45 & $4,078.50$ & 29.90 \\
\hline 30 & $5,917.01$ & 88.46 & $3,646.86$ & 16.16 & $4,779.43$ & 52.23 \\
\hline
\end{tabular}

Tabel 8. Kebutuhan investasi (Rp).

Table 8. Equipment investment (Rp).

\begin{tabular}{lccccc}
\hline $\begin{array}{c}\text { Bahan } \\
\text { Materials }\end{array}$ & $\begin{array}{c}\text { Jumlah perolehan } \\
\text { Procurement } \\
\text { number } \\
\text { (unit) }\end{array}$ & $\begin{array}{c}\text { Biaya/unit } \\
\text { Cost/unit }\end{array}$ & $\begin{array}{c}\text { Jumlah } \\
\text { biaya } \\
\text { Total cost } \\
\text { (Rp) }\end{array}$ & $\begin{array}{c}\text { Usia ekonomis } \\
\text { Economic live }\end{array}$ & $\begin{array}{c}\text { Depresiasi } \\
\text { Depreciation }\end{array}$ \\
\hline Pisau (Knife) & 2 & 2,000 & 4,000 & 2 & $(\mathbf{Y})$ \\
Talenan (Chopping board) & 2 & 1,000 & 2,000 & 2 & (Rp) \\
Ember (Bucket) & 2 & 1,000 & 2,000 & 2 & 4.17 \\
Waskom (Washbasin) & 3 & 1,000 & 3,000 & 2 & 4.17 \\
Pengocok (Mixer) & 1 & 75,000 & 75,000 & 5 & 104.17 \\
Noodles forming & 1 & 25,000 & 25,000 & 5 & 34.72 \\
Nampan (Trays) & 20 & 500 & 10,000 & 1 & 41.67 \\
Nampan (Trays) & 20 & 1,000 & 20,000 & 2 & 41.67 \\
Pemanggan(Oven) & 1 & 50,000 & 50,000 & 2 & 104.17 \\
Kompor (Stove) & 1 & 50,000 & 50,000 & 2 & 104.17 \\
\hline Total & & & 216,000 & & 433,49 \\
\hline
\end{tabular}

Pada penambahan daging surimi ikan layang ke dalam mie sebanyak $10 \%$ umumnya dapat diterima oleh panelis, karena warnanya kekuning-kekuningan, rupanya menarik, dan baunya netral. Sedangkan pada penambahan daging ikan ke dalam mie sebesar $20 \%$ dan $30 \%$, warna kurang menarik karena terdapat bintik- bintik seperti noda, terasa ikan, bau ikan dan teksturnya lebih keras.

\section{Analisis Biaya}

Biaya dibedakan menjadi dua, yaitu biaya tidak tetap dan biaya tetap. Biaya tidak tetap atau biaya produksi adalah biaya yang dikeluarkan sebagai akibat berlangsungnya produksi seperti pembelian bahan, upah dan sebagainya.
Biaya total adalah jumlah keseluruhan biaya, baik biaya tetap maupun biaya tidak tetap, yang secara matematis dapat ditulis sebagai berikut: Total biaya $=$ Biaya tetap + Biaya tidak tetap. Biaya pulang pokok (BPP) akan dicapai jika penerimaan sama besarnya dengan jumlah total biaya. Dengan dasar pemikiran tersebut, dilakukan perhitungan terhadap biaya pembuatan mie telur kering dengan penambahan surimi ikan layang.

Biaya tetap adalah biaya yang dikeluarkan sebagai akibat berdirinya industri pengolahan atau biaya yang besarnya tidak dipengaruhi oleh aktivitas produksi atau biaya yang besarnya tidak dipengaruhi oleh produk yang akan dihasilkan. Biaya tetap ini antara lain berupa penyusutan alat, dan pajak. 
Perhitungan-perhitungan yang dilakukan seperti tertera dalam Tabel 3 sampai Tabel 8 . Dari perhitungan biaya produksi untuk produk mie ikan diperoleh hasil bahwa harga mie ikan relatif masih di atas harga mie pasaran. Harga mie yang ada di pasaran umum tanpa penambahan daging ikan, adalah Rp 2000-3000/ kg. Sedangkan pada musim ikan sepi harga pokok mie ikan layang (10\%) Rp $3.645,75 / \mathrm{kg}$. Pada musim ikan layang harga pokok mie ikan $(10 \%)$ Rp 2.885,20/kg. Harga rata-rata ikan layang basah $\mathrm{Rp} 1.750 / \mathrm{kg}$, biaya produksi untuk produk mie ikan diperoleh harga $\mathrm{Rp} 1.733,15$ / resep atau Rp 3.265,47/kg.

Namun demikian, harga tersebut di atas baru diperhitungkan berdasarkan biaya-biaya produksi pokok saja. Biaya pengemasan, promosi, transportasi dan sebagainya masih belum di perhitungkan. Dengan demikian, untuk mendapatkan harga jual riil masih harus di perhitungkan lagi. Namun jika dilihat perbedaan harga tersebut, harga mie ikan tampaknya masih lebih tinggi. Perbedaan harga tersebut kemungkinan dapat ditolerir oleh konsumen, sepanjang mie ikan unggul dalam segi rasa, kandungan protein dan penampilan.

\section{KESIMPULAN}

Produk mie telur kering dengan penambahan daging surimi ikan layang sebesar $10 \%$ paling disukai oleh panelis, sedangkan penambahan daging surimi ikan lebih dari $20 \%$ kurang di- sukai. Penambahan daging surimi ikan layang ke dalam adonan sebesar $10 \%$, dapat meningkatkan kadar protein mie dari $12,90 \%$ hingga $13,53 \%$, dengan harga dasar rata-rata $\mathrm{Rp} 3.265,47 / \mathrm{kg}$.

\section{DAFTAR PUSTAKA}

Anonim. 1984. Pokok-pokok kebijaksanaan dan evaluasi pembangunan pelabuhan perikanan dan-pusat pendaratan ikan. Direktorat Jenderal Perikanan. Jakarta.

Ariyoto dan Kresnohadi. 1978. Feasibility study. Penerbit Mutiara, Jakarta, Edisi Ke 1.

Henderson, J.M. and R.E. Quant. 1980. Microeconomic theory: A mathematical approach. Mc.Graw Hill Inc., Auckland.

Jamal Basmal; Sugiyono; Rosmawati Peranginangin; dan Mohammad Noor. 1995. Pengaruh fortifikasi surimi layang terhadap mutu mie kering selama penyimpanan. Jurnal Penelitian Pasca Panen Perikanan. No 84.

Maltz, M.A. 1981. Cooking and craker technology. The AVI Publishing Co. Wesport. Connecticut.

Nicholson, W. 1978. Microeconomic theory. The Dryden Press, Hinsdale.

Peter. 1982. Plant design and economics for chemical engineer, chemical engeneering, plant design and economics. McGraw-Hill, Kogakusta.

Riyanto, B. 1980. Dasar-dasar pembelanjaan perusahaan. Yayasan Badan Penerbitan Gajah Mada. Yogyakarta.

Reksoprayitno, S. 1981. Ekonomi mikro. Perilaku harga dan konsumen. Liberty. Yogyakarta. 